\title{
Growth performance and carcass characteristics of Nelore Angus and Nelore Angus Guzera crossbreed cows fed with supplemented pasture during the yearling and feedlot stages
}

\section{Desempenho e Características de carcaça de bovinos mestiços suplementados em pasto e terminados em confinamento}

\author{
Eduardo Eustáquio Mesquita ${ }^{1 *}$; Deise Dalazen Castagnara ${ }^{2}$; \\ Newton Tavares Escocard de Oliveira ${ }^{3}$; Alan Cardias Figueiredo \\ Aparecida da Costa Oliveira ${ }^{5}$
}

\begin{abstract}
The objective of this study was to evaluate the growth performance of two crossbreed genetic groups, $1 / 2$ Nelore $1 / 2$ Angus and $1 / 4$ Nelore $1 / 4$ Angus $1 / 2$ Guzera, which originate from the rotational crosses of Nellore cows with Angus bulls and $1 / 2$ Nellore $1 / 2$ Angus cows with Guzera bulls, respectively. The growth performance was evaluated at the end of the yearling and feedlot stages, and carcass characteristics were evaluated after the slaughter. A completely randomized trial design was used, with 12 cows in each group. The yearling stage lasted 270 days, and the cattle were fed with pasture of Brachiaria brizantha 'Marandu' with $2.0 \mathrm{UA} \mathrm{ha}^{-1}$ and a forage allowance of $2.5 \mathrm{~kg}$ of dry matter (DM) per $100 \mathrm{~kg}$ of live weight (LW), during this stage the animals, with an average age of $365 \pm$ 10 days, received protein and energy supplementation ad libitum. After the yearling stage, the cows were confined until they reached the age of 22-24 months and received $6.0 \mathrm{~kg}$ DM of sugar cane + urea and $4.0 \mathrm{~kg}$ DM of concentrate, with $150 \mathrm{~g} \mathrm{~kg}^{-1}$ of crude protein (CP), daily during 90 days. The daily average weight gain (DAWG) during the yearling stage was higher for the $1 / 2$ Nelore $1 / 2$ Angus group. The $1 / 4$ Nelore $1 / 4$ Angus $1 / 2$ Guzera group reached higher slaughter weight because they had higher DAWG during the feedlot stage (1.022 vs. $\left.728 \mathrm{~g} \mathrm{dia}^{-1}\right)$. No significant difference $(\mathrm{P}>0.05)$ was found between the groups when the hot carcass weights were compared. The $1 / 2$ Nelore $1 / 2$ Angus group reached a higher carcass weight percentage (53 vs. $50 \%$ ) and subcutaneous fat thickness (4.3 vs. $4.0 \mathrm{~mm}$ ).
\end{abstract}

Key words: Bos indicus. Correlation coefficient. Fat thickness. Weight gain.

\section{Resumo}

Conduziu-se o experimento para avaliar o desempenho e as características da carcaça de dois grupos genéticos de bovinos mestiços, $1 / 2$ Nelore $1 / 2$ Angus e 1/4 Nelore $1 / 4$ Angus 1/2 Guzerá, provindo, respectivamente, de dois cruzamentos rotativos: vacas nelore acasaladas com touro angus e vacas

\footnotetext{
${ }^{1}$ Prof. Associado, Universidade Estadual do Oeste do Paraná, UNIOESTE, Marechal Cândido Rondon, PR, Brasil. E-mail: e-mesquita@bol.com.br

2 Prof $^{a}$ Assistente, Universidade Federal do Pampa, UNIPAMPA, Uruguaiana, PR Brasil. E-mail: deisecastagnara@yahoo.com.br

3 Prof. Adjunto, UNIOESTE, Marechal Cândido Rondon, PR, Brasil. E-mail: newtonescocard@hotmail.com

4 Zootecnista, UNIOESTE, Marechal Cândido Rondon, PR, Brasil. E-mail: alancfigueiredo@hotmail.com

5 Bolsista Pós-Doutor do Programa de Pós-Graduação em Zootecnia, UNIOESTE, Marechal Cândido Rondon, PR, Brasil. E-mail: aparecidacostaoliveira@gmail.com

* Author for correspondence
} 
$1 / 2$ Nelore $1 / 2$ Angus acasaladas com touro Guzerá. O desempenho foi avaliado em pasto na fase de sobreano e no confinamento e as características da carcaça avaliadas no abate. O delineamento experimental foi inteiramente ao acaso com 12 animais de cada grupo. Foi utilizado, no período de sobreano, 270 dias, pastagem de Brachiaria brizantha cv. Marandu com 2,0 unidades animal ha-1, oferta de 2,5 kg de matéria seca (MS) por $100 \mathrm{~kg}$ de peso vivo (p.v.), nesse período os animais, de $365 \pm 10$ dias de idade média inicial, receberam suplementação proteica-energética ad libitum. Após o período de sobreano, os animais foram confinados em baias individuais com 21-22 meses de idade, nas quais foram fornecidos cana-de-açúcar + ureia, 6,0 kg de MS; e concentrado, 4,0 kg de MS, sendo 150 $\mathrm{g} \mathrm{kg}^{-1}$ de proteína bruta (PB), diariamente, durante 90 dias. O ganho médio de peso diário (GMPD) na fase de sobreano foi maior no grupo bimestiço 1/2 Nelore $1 / 2$ Angus. Os animais do grupo $1 / 4$ Nelore $1 / 4$ Angus $1 / 2$ Guzerá obtiveram maior peso ao abate em razão do maior GMPD no confinamento (1.022 contra $\left.728 \mathrm{~g} \mathrm{dia}^{-1}\right)$. Não houve diferença $(\mathrm{P}>0,05)$ entre os grupos no peso de carcaça quente, porém no grupo $1 / 2$ Nelore $1 / 2$ Angus foram obtidos maiores rendimento de carcaça e espessura de gordura $(4,3$ contra $4,0 \mathrm{~mm}$ ).

Palavras-chave: Bos indicus. Coeficiente de correlação. Espessura de gordura. Ganho de peso.

\section{Introduction}

National beef cattle herds have shown improvements in the quantity and quality of the carcasses produced. This was achieved through the selection of suitable animals, the use of a balanced diet, and the use of appropriate breeding, rebreeding, and finishing methods.

To select the appropriate genetic group, the one that produces heavier animals and better-quality carcasses should be considered. Almost $90 \%$ of the Brazilian herds belong to the Bos indicus genotype, which is habituated to the tropical conditions, but has some unwanted characteristics in this climate, such as low meat production (AZEVEDO et al., 2005; RIBEIRO et al., 2009). One of the strategies to increase meat production is to use genetically improved animals (CRUZ et al., 2009), because the genotype influences the performance of the animals (PIMENTEL et al., 2005), and crossbreeding allows the use of the genetic capacity of the animals, which allows the producer to take advantage of the complementarity of different breeds (PADUA et al., 2004).

Crossbred animals show greater weight gain owing to heterosis (PIMENTEL et al., 2005). However, animals crossbred using three different breeds show higher performance than pure and half-blood animals, owing to direct maternal heterosis (EUCLIDES FILHO, 2003), which accounts for the increase in multibreed populations in Brazil and worldwide (LOPES et al., 2010a).

The majority of the Brazilian cattle are fed on pastures (LIMA et al., 2004). Among the cultivated grasses, the genus Brachiaria, which occupies approximately 60 million hectares, constitutes the main option for feeding beef cattle in the country (SÁ et al., 2011), especially in the growing and fattening stages.

However, a lower performance with lower average daily weight gains (ADWG) and higher fattening period is observed when using pasture systems or systems with more fodder on the diet (CUVELIER et al., 2006), in particular when supplementation is not used. Conversely, in the feedlot, the animals are fed considering their nutritional requirements and different genetic potentials (YANG et al., 2009).

Some studies have been carried out (LEME et al., 2000; SILVA et al., 2004; RIBEIRO et al., 2008) to evaluate the performance of purebreds and crossbreds under several modes of growing and fattening; however, more studies are required to compare different breeds of cattle that are under the same production system (CUVELIER et al., 2006). 
Based upon the discussion presented above, the aim of this study was to compare the performance and characteristics of the carcasses of two genetic groups during the growing stage with supplementation and the fattening stage in the feedlot. We evaluated the performance and characteristics of the genetic groups $1 / 2$ Nelore $1 / 2$ Angus and $1 / 4$ Nelore $1 / 4$ Angus $1 / 2$ Guzerá, which originate from the rotational crosses of Nelore cows mated with Angus bulls and 1/2 Nelore $1 / 2$ Angus cows mated with Guzerá bulls, respectively.

\section{Material and Methods}

The study was performed from August to November, at the San Antonio farm facilities, located in the municipality of Realeza, PR, in the south-west of Paraná, $25^{\circ} 46^{\prime}$ '08” South Latitude and $53^{\circ} 31^{\prime} 57^{\prime}$ " West Longitude and altitude of $520 \mathrm{~m}$. Taking into account the Koppen climate classification, the humid subtropical climate, mesothermal, and the climatic data for the duration of the experiment are presented in Table 1.

Table 1. Average monthly temperatures of the minimum, maximum, and average daily temperatures, average evapotranspiration, and average monthly rainfall, during the yearling stage in the pasture, until the entrance in the feedlot, in the municipality of Realeza-PR.

\begin{tabular}{lccccc}
\hline Month/year & $\begin{array}{c}\text { Minimum } \\
{ }^{\circ} \mathrm{C}\end{array}$ & $\begin{array}{c}\text { Maximum } \\
{ }^{\circ} \mathrm{C}\end{array}$ & $\begin{array}{c}\text { Average } \\
{ }^{\circ} \mathrm{C}\end{array}$ & $\begin{array}{c}\text { Evapotransp. } \\
\mathrm{mm}\end{array}$ & $\begin{array}{c}\text { Rainfall } \\
\mathrm{mm}\end{array}$ \\
\hline August & 15.1 & 27.5 & 21.2 & 25.0 & 224.0 \\
September & 15.3 & 27.3 & 21.3 & 27.3 & 436.0 \\
October & 18.2 & 30.1 & 24.1 & 39.8 & 359.9 \\
November & 17.9 & 26.9 & 22.4 & 37.0 & 210.0 \\
December & 19.0 & 28.9 & 24.0 & 45.6 & 171.6 \\
January & 19.5 & 29.1 & 24.3 & 45.5 & 169.0 \\
February & 19.2 & 30.1 & 24.7 & 31.4 & 122.0 \\
March & 18.6 & 27.8 & 23.1 & 32.2 & 99.0 \\
April & 18.2 & 28.4 & 23.3 & 26.5 & 127.7 \\
May & 15.4 & 24.5 & 19.5 & 20.1 & 238.9 \\
\hline
\end{tabular}

The animals used in the study originated from two herds of distinct genetic groups, kept on pasture, in a creep feeding system, with an age of 60 to 210 days, and supplemented in the pasture until the beginning of the experiment, in the yearling, at $365 \pm 10$ days old. The animals were weaned between $180 \pm 27 \mathrm{~kg}$ and $210 \pm 15$ days old, with 12 animals belonging to the genetic group $1(1 / 2$ Nelore $1 / 2$ Angus) and 12 animals to the genetic group $2(1 / 4$ Nelore $1 / 4$ Angus $1 / 2$ Guzerá), which originated from the rotational crosses of Nelore cows mated with Angus bulls and 1/2 Nelore $1 / 2$ Angus cows mated with Guzerá bulls, respectively.

The experiment was performed in two stages. During the first stage, from August to May, the animals were raised on pastures with Brachiaria brizantha $\mathrm{cv}$. Marandu, fertilized with $120 \mathrm{~kg} \mathrm{ha}^{-1}$ $\mathrm{ano}^{-1}$ of $\mathrm{N}$. At this stage, the average environmental temperature was $23{ }^{\circ} \mathrm{C}$ and the average monthly precipitation was above $120 \mathrm{~mm}$, except in March when the average precipitation was $99 \mathrm{~mm}$. This climate is known to be adequate for the growth of the fodder used in the study. At the dates of weighing the animals (Figure 2), forage samples were collected to determine the content of dry matter (DM), crude protein (CP), neutral detergent fiber (NDF), and acid detergent fiber (ADF) in the forage and forage allowance. The forage allowance were administered at a rate of $2.5 \mathrm{~kg}$ of DM per 100 $\mathrm{kg}$ live weight; for this, control cattle was used with 
the technique 'put and take' and the pasture area was controlled with a mobile fence. The average levels of DM, CP, NDF, and ADF in the growing stage under grazing were 266, 75, 530, and 420 $\mathrm{g} \mathrm{kg}^{-1}$, respectively. During this stage the animals received protein and energy supplementation ad libitum (NDT-750, PB-240, P-5,2, Ca-2,4, and EE-33 $\left.\mathrm{g} \mathrm{kg}^{-1}\right)$. In the second stage, the animals were housed in individual corrals for 90 days. The animals were fed with $10.0 \mathrm{~kg}$ of DM per day ( $6.0 \mathrm{~kg}$ of roughage $+4.0 \mathrm{~kg}$ concentrate) as a full ration (Table 2), with $740 \mathrm{~g} \mathrm{~kg}^{-1}$ of NDT and 150 $\mathrm{g} \mathrm{kg}^{-1}$ of $\mathrm{CP}$, an amount estimated to be consumed by $21 \mathrm{~g} \mathrm{~kg}^{-1}$ of live weight with an average daily weight gain of $1.10 \mathrm{~kg}$. The total daily ration was divided into three parts and fed throughout the day. Each time the animals were fed, the leftovers were weighed in order to estimate the DM intake. When moved to the feedlot, the animals were adjusted to the diet and were fed with $25 \%$ of the concentrate in the first three days, $50 \%$ up to day $6,75 \%$ up to day 9 and $100 \%$ from day 10 onwards.

Table 2. Chemical composition and concentration of the ration.

\begin{tabular}{lccc}
\hline \multicolumn{1}{c}{ Ingredients } & $\begin{array}{c}\mathrm{DM} \\
\mathrm{kg}\end{array}$ & $\begin{array}{c}\text { NDT inna DM } \\
\mathrm{g} \mathrm{kg}^{-1}\end{array}$ & PB in DM \\
\hline Soybean Bran & 160.0 & 503.2 & 75.2 \\
Corn Meal & 592.0 & 144.0 & 59.2 \\
Calcareous & 40.0 & - & - \\
Nucleus & 8.0 & 5.2 & 3.2 \\
Sugarcane and urea & 200.0 & 92.0 & 15.2 \\
Total & 1000.0 & 744.4 & 152.8 \\
\hline
\end{tabular}

Nucleus: calcium-8.0 g; phosphor -4.87 g; sulphur-6.0 g; chrome-1.55 g; cobalt-1.0 g; zinc-0.3 g; sodium-31.2 g; manganese-0.2 $\mathrm{g}$; copper- $0.6 \mathrm{~g}$; crude protein-400 $\mathrm{g} \mathrm{kg}^{-1}$; NDT-400 g/kg; humidity-10 $\mathrm{g} \mathrm{kg}^{-1}$.

During the growing stage in the yearling, the animals were weighed monthly and the initial weight and average daily weight gain were assessed. The slaughter was carried out at 24 months of age, after a fasting period of 16 hours, and the following characteristics were determined: slaughter weight, average daily weight gain in the feedlot, feed conversion, hot carcass weight, carcass yield and fat thickness on the $12^{\text {th }}$ rib, using calipers.

The results were submitted to analysis of variance, using the Sisvar program (FERREIRA, 2011), and the averages of the treatments were compared using the $\mathrm{F}$ test at 5\% probability. For regression analysis, the significance of the regression coefficients of 1 and 5\% was determined using a $t$-test. A correlation analysis between random variables was performed.

\section{Results and Discussion}

The weights of the animals of both genetic groups were studied as a function of time obtained monthly during the yearling stage and adjusted to the linear model (Figure 1), considering the significance of the regression coefficients. Lôbo and Martins Filho (2002) compared various models, which describe the growth of Nelore beef cattle, and reported that although the nonlinear models de Richards $\left(\mathrm{R}^{2}=0.99\right)$ and Brody $\left(\mathrm{R}^{2}=0.99\right)$ have a better fit, the quality of the fit of the linear model $\left(\mathrm{R}^{2}=0.97\right)$ is similar to that of nonlinear models.

The genetic group 1/4 Nelore $1 / 4$ Angus 1/2 Guzerá showed greater weights throughout the yearling stage. The fact that this group had a greater initial average weight in the growing stage (319 kg) 
contributed to the greater weight observed in the However, for the group $1 / 2$ Nelore $1 / 2$ Angus had following assessments throughout the growing the highest regression coefficient (b), which stage of the animals at the yearling (Table 3). demonstrates a higher estimated daily gain.

Figure 1. Weights of beef cattle of the group $1 / 4$ Nelore $1 / 4$ Angus $1 / 2$ Guzerá and $1 / 2$ Nelore $1 / 2$ Angus during the yearling stage.

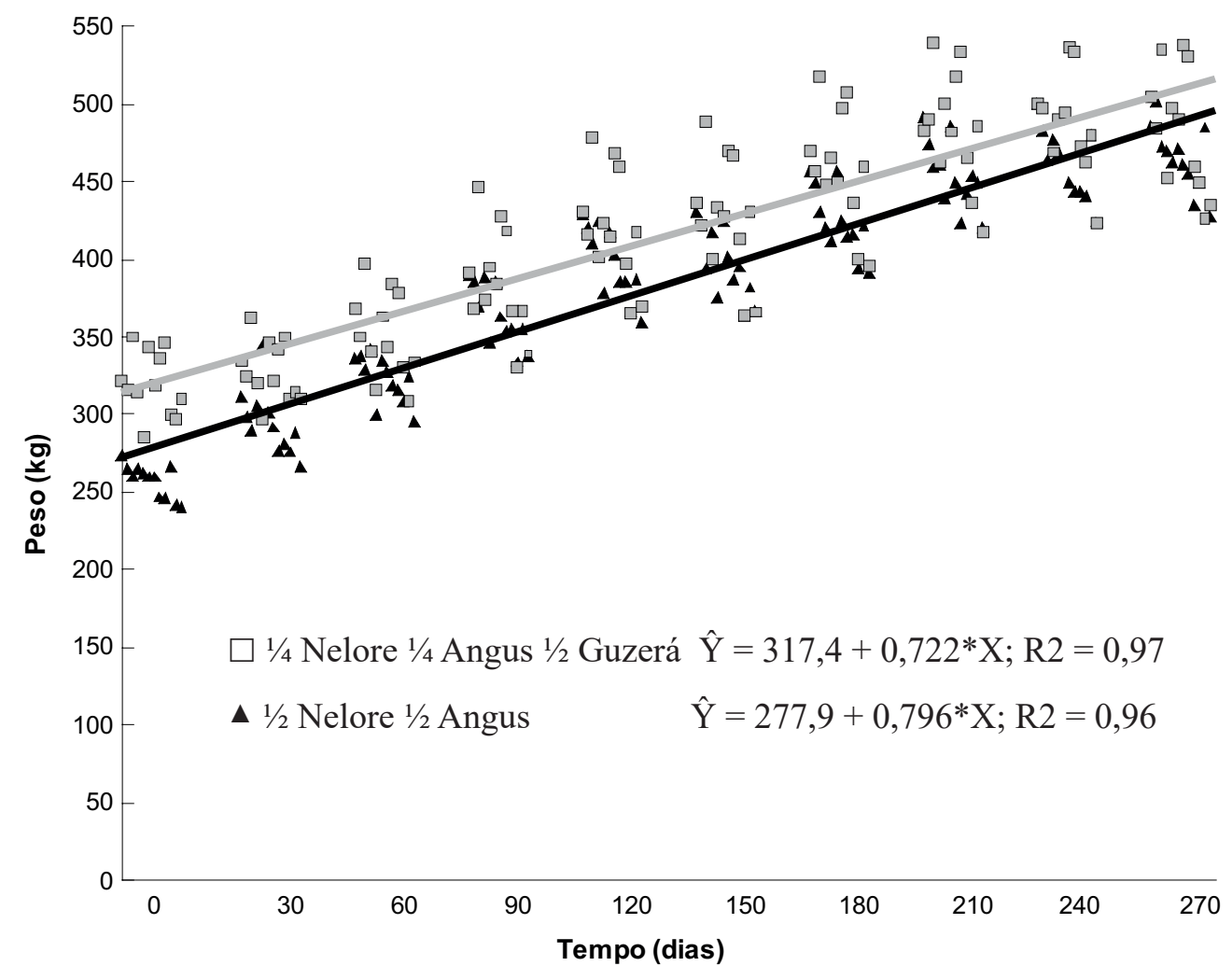

* Significant at $1 \%$ probability by the $t$-test.

There was a higher average weight gain during the growing stage of the $1 / 2$ Nelore $1 / 2$ Angus group (Table 3), which represents an increase of $10.15 \%$ when compared with the group $1 / 4$ Nelore $1 / 4$ Angus $1 / 2$ Guzerá. It might be due to several factors, such as higher heterosis for weight gain of the half-blood group (which theoretically would be $100 \%$ in both groups), better response to supplementation in the pasture, and greater initial weight in the growing stage. Perotto et al. (2000) observed the heterosis effect on the weight gain of crossbred cattle Charolais/Nelore.
The greater weight gain of the group $1 / 2$ Nelore $1 / 2$ Angus is contrary to the notion that animals originated from crosses of the three breeds have higher performances than pure or half-blood animals owing to direct maternal heterosis (EUCLIDES FILHO, 2003). However, the lower weight gain in the $1 / 4$ Nelore $1 / 4$ Angus $1 / 2$ Guzerá group may be due to genetic proximity between Nelore and Guzerá breeds, thus reducing the effect of heterosis in the gain. Ribeiro et al. (2008) found no heterosis effect on the performance of $1 / 2$ Nelore $1 / 2$ Guzerá and, according to the authors, this is probably due 
to the genetic similarity between these two groups. Crosses maximize the effect of heterosis (LOPES et al., 2010b), and are used to increase the rate of growth and fattening of the animals (LOPES et al., 2008).

It is relevant to highlight the importance of supplementation in the growing phase, $8 \mathrm{~g} /$ $\mathrm{kg}$ per day, to obtain greater weight gains and final weights. Goes et al. (2009) observed greater weight gains and final weights on Nelore beef cattle and crossbreds in pastures with $B$. brizantha during the dry season, with protein and energy supplementation of $10 \mathrm{~g} / \mathrm{kg}$. However, supplementation only during the first dry season did not contribute to higher yields and quality of the carcasses in the growing stage of beef cattle F1 Angus-Nelore (FEIJÓ et al., 2001).

Table 3. Performance of beef cattle during the yearling stage ( 270 days) for the different genetic groups.

\begin{tabular}{lccc}
\hline \multicolumn{1}{c}{ Genetic Group } & $\begin{array}{c}\text { Weight at the beginning } \\
\text { of the growing stage } \\
\mathrm{kg}\end{array}$ & $\begin{array}{c}\text { Weight gain during the } \\
\text { growing stage } \\
\mathrm{kg} \mathrm{day}^{-1}\end{array}$ & $\begin{array}{c}\text { Weight at the end of the } \\
\text { growing stage } \\
\mathrm{kg}\end{array}$ \\
\hline $1 / 2$ Nelore $1 / 2$ Angus & $255 \mathrm{~b}$ & $0.727 \mathrm{a}$ & $453 \mathrm{~b}$ \\
$1 / 4$ Nelore $1 / 4$ Angus $1 / 2$ Guzerá & $319 \mathrm{a}$ & $0.660 \mathrm{~b}$ & $486 \mathrm{a}$ \\
Variation Coefficient $(\%)$ & 7.55 & 13.77 & 7.48 \\
\hline
\end{tabular}

* Significant at $5 \%$ probability by the $\mathrm{F}$ test.

The greater final weights obtained in the growing stage for the $1 / 4$ Nelore $1 / 4$ Angus $1 / 2$ Guzerá group suggest that the time of supplementation in the pasture is flexible and allows a reduction in time and a decrease in cost of supplementation. On the other hand, Assad et al. (2015) observed that the additional daily weight gains of Nelore beef cattle using several supplement formulations, compensates for the daily costs of supplementation.

The greater initial weight in the growing stage led to a greater weight of the $1 / 4$ Nelore $1 / 4$ Angus $1 / 2$ Guzerá group at the beginning of the feedlot stage (Table 4). On the other hand, the $1 / 2$ Nelore $1 / 2$ Angus group, despite of having a greater weight gain, did not reach the weight of the first group. Ferreira et al. (2009) emphasized the importance of the weight of the animals at the start of the feedlot stage.

The $1 / 4$ Nelore $1 / 4$ Angus $1 / 2$ Guzerá group reached a higher weight at the time of slaughter $(8.7 \%$ higher), probably due to a higher daily weight gain in the feedlot (Table 4). Kippert et al. (2008) observed large differences in performance between animals of the same group, $1 / 2$ Nelore $1 / 2$ Angus. The greater slaughter weight of the $1 / 4$ Nelore $1 / 4$ Angus $1 / 2$ Guzerá group did not lead to a higher hot carcass weight, with an increase of only $2.75 \%$ in carcass weight.

There was a higher carcass yield for the $1 / 2$ Nelore $1 / 2$ Angus group, in agreement with Muchenje et al. (2008) who reported a carcass yield of 53\% for animals of the Angus breed. It is observed (Table 4) that there was a compensatory effect between slaughter weight and hot carcass yield, i.e., a lower carcass weight is compensated by a higher carcass yield. This higher yield, the lower carcass weight and the higher fat thickness show a higher precocity on the $1 / 2$ Nelore $1 / 2$ Angus group. This group, according to Silva Goulart et al. (2008), has a greater demand in net energy per kg gain, which negatively affects the feed conversion but generates better animals in the finishing process.

No difference was found $(\mathrm{P}<0.05)$ between genetic groups with respect to feed conversion in the feedlot stage (Table 4). Perotto et al. (2000) found 
no significant effect $(\mathrm{P}>0.05)$ of heterosis on feed conversion and consumption of DM in Charolais, Caracu, and alternate cross cattle. Although not statistically significant, the difference in feed conversion between the groups may be economically relevant, since it represents a decrease of $55.8 \mathrm{~kg} / \mathrm{kg}$ of fed food per animal on the $1 / 4$ Nelore $1 / 4$ Angus $1 / 2$
Guzerá group, over a period of 90 days in the feedlot. Since food costs represent an average of $77.2 \%$ of the total beef cattle production costs (RESTLE et al., 2007), feed efficiency is an important factor for the identification of more efficient crosses, which may lead to more economically and environmentally sustainable herds (LANCASTER et al., 2008).

Table 4. Performance and carcass quality of beef cattle from different genetic groups in the feedlot.

\begin{tabular}{|c|c|c|c|c|c|c|c|}
\hline \multirow{2}{*}{ Group } & CIW & SW & $\mathrm{HCW}$ & WGF & FC & $\mathrm{CY}$ & FT \\
\hline & \multicolumn{3}{|c|}{$\begin{array}{l}\text {------------ kg ------------ } \\
\end{array}$} & $\mathrm{kg} \mathrm{dia}^{-1}$ & $\mathrm{~kg} \mathrm{~kg}^{-1}$ & $\%$ & $\mathrm{~mm}$ \\
\hline $1 / 2$ Nelore $1 / 2$ Guzerá & $453 b$ & $549 b$ & $291 \mathrm{a}$ & $0.728 b$ & $8.36 \mathrm{a}$ & $53 a$ & $4.3 \mathrm{a}$ \\
\hline $1 / 4$ Nelore $1 / 4$ Angus $1 / 2$ Guzerá & $486 \mathrm{a}$ & $597 \mathrm{a}$ & $299 \mathrm{a}$ & $1.022 \mathrm{a}$ & $7.74 \mathrm{a}$ & $50 \mathrm{~b}$ & $4.0 \mathrm{~b}$ \\
\hline Variation Coefficient (\%) & 7.48 & 5.80 & 5.37 & 28.33 & 22.30 & 3.95 & 5.70 \\
\hline
\end{tabular}

IW., initial weight; SW., slaughter weight; HCW., hot carcass weight; WGF, weight gain in the feedlot; FC., feed conversion; CY., carcass yield and FT., fat thickness. * Significant at $5 \%$ probability by the $\mathrm{F}$ test.

A positive correlation was observed $(\mathrm{r}=0.49)$ between the initial weight in the growing stage and the initial weight in the feedlot stage (Table 5), supporting the results of Vieira et al. (2005), who observed a positive correlation $(r=0.70)$ between the initial weight and the weight at the end of supplementation during the growing stage of Nelore cattle. This finding emphasizes the importance of supplementation during the growing stage in order to obtain heavier animals at the beginning of the feedlot stage, because animals with feed restrictions at this stage rarely reach the initial weights, although they may have a compensatory gain.

The higher positive correlation coefficients between the initial weight in the feedlot and slaughter weight $(\mathrm{r}=0.70)$ and between the slaughter weight and carcass weight $(\mathrm{r}=0.75)$ can be observed in Table 5 According to Reinhardt et al. (2009), in the United States, the initial weight in the feedlot in 19 feedlot systems for beef cattle (Angus and continental races) was positively correlated with the final weight.

Table 5. Pearson correlation coefficients between the variables studied.

\begin{tabular}{lcccccccc}
\hline & WGG & IWF & SW & WFG & HCW & CY & FT & FC \\
\hline IWG & -0.05 & $0.49^{*}$ & $0.57^{*}$ & $-0.36^{*}$ & $0.38^{*}$ & $-0.38^{*}$ & $-0.60^{*}$ & 0.12 \\
WGG & - & 0.31 & $0.39^{*}$ & 0.12 & 0.33 & -0.18 & 0.28 & 0.09 \\
IWF & - & - & $0.70^{*}$ & $-0.36^{*}$ & $0.55^{*}$ & -0.36 & $-0.45^{*}$ & $-0.40^{*}$ \\
SW & - & - & - & $0.41^{*}$ & $0.75^{*}$ & $-0.59^{*}$ & -0.26 & $-0.39^{*}$ \\
WGF & - & - & - & - & $0.28^{*}$ & $-0.29^{*}$ & 0.25 & $-0.58^{*}$ \\
HCW & - & - & - & - & - & 0.09 & 0.01 & 0.22 \\
CY & - & - & - & - & - & - & $0.38^{*}$ & 0.16 \\
FT & & & & & & & - & 0.21 \\
\hline
\end{tabular}

IWG., initial weight in the growing stage; WGG., weight gain in the growing stage; IWF., initial weight in the feedlot; SW., slaughter weight; WGF., weight gain in the feedlot; HCW., hot carcass weight; CY., carcass yield and FT., fat thickness; FC., feed conversion; * Significant at $5 \%$ probability by the $t$-test. 
A high average daily weight gain in the feedlot stage can lead to the reduction of production costs since the animals with a higher average daily gain reach the slaughter weight in a shorter period of time. The initial weight in the feedlot stage showed a negative correlation with the daily weight gain (Table 5), supporting the results of Reinhardt et al. (2009), who reported that an increase in the initial weight led to a lower daily weight gain. Animals with a genetic background for fast growth reached the highest weights at a particular time; however, fat deposition in these animals was delayed (LABORDE et al., 2001), which extended the feedlot stage.

Restle et al. (2002) observed a high positive correlation ( $\mathrm{r}=0.94 ; \mathrm{P}=0.0001)$ between slaughter weight and cold carcass weight in half-blood $(1 / 2$ Nelore $1 / 2$ Charolais) cattle and low correlations between slaughter weight and cold carcass yield $(\mathrm{r}=0.06)$, and between cold carcass weight and fat thickness (0.11). Silva et al. (2004) observed a positive linear association between the fat layer at the $12^{\text {th }}$ and $13^{\text {th }}$ ribs, and the weight of living animals, but with high variability in fat thickness for the same weight of live Nelore and Brangus animals. In this study, the weights of living animals negatively correlated with the fat thickness (Table 5). This contrasting result may be due to the high variability of this feature (SILVA et al., 2004) for animals of the same weight.

No correlation was found between hot carcass weight and carcass yield (Table 5), but the slaughter weight was negatively correlated with the carcass yield, indicating that slaughter weight is more significant than the hot carcass weight for the yield.

\section{Conclusions}

The $1 / 2$ Nelore $1 / 2$ Angus genetic group had a better growth performance during the yearling stage, as well as, higher precocity than the $1 / 4$ Nelore
$1 / 4$ Angus $1 / 2$ Guzerá group. In the feedlot stage, the $1 / 4$ Nelore $1 / 4$ Angus $1 / 2$ Guzerá group had a better performance and the $1 / 2$ Nelore $1 / 2$ Angus group had better performance in terms of yields and carcass finishing. The initial weights of the animals in the yearling and feedlot stages correlate positively.

\section{Acknowledgments}

To the fridge JBS S.A., Maringá-PR unit, for providing the facilities to evaluate the animal carcasses.

\section{References}

ASSAD, L. V. de F.; ZERVOUDAKIS, J. T.; CABRAL, L. da S.; HATAMOTO-ZERVOUDAKIS, L. K.; PAULINO, P. V. R.; MORAES, E. H. B. K. de; SILVAMARQUES, R. P. da; KOSCHECK, J. F. W. Proteína degradável no rúmen e frequência de suplementação para novilhos Nelore em pastejo: Desempenho produtivo e análise econômica. Semina: Ciências Agrárias, Londrina, v. 36, n. 3, p. 2105-2118, 2015. Suplemento 1.

AZEVEDO, C. A.; MOURA, A. A. A.; LÔBO, R. N. B.; MODESTO, E. C.; MARTINS FILHO, R. Avaliação de fatores não genéticos sobre características de peso em bovinos Nelore e Guzerá no Estado do Rio Grande do Norte. Revista Ciência Agronômica, Fortaleza, v. 36, n. 2, p. 227-236, 2005

CRUZ, G. M.; RODRIGUES, A. A.; TULLIO, R. R.; ALENCAR, M. M.; ALLEONI, G. F.; OLIVEIRA, G. P. Desempenho de bezerros da raça Nelore e cruzados desmamados recebendo concentrado em pastagem adubada de Cynodon dactylon cv. Coastcross. Revista Brasileira de Zootecnia, Viçosa, MG, v. 38, n. 1, p. 139148, 2009.

CUVELIER, C.; CABARAUX, J. F.; DUFRASNE, I.; CLINQUART, A.; HOCQUETTE, J. F.; ISTASSE, L.; HORNICK, J. L. Performance, slaughter characteristics and meat quality of young bulls from Belgian Blue, Limousin and Aberdeen Angus breeds fattened with a sugar-beet pulp or a cereal-based diet. Animal Science, Liverpool, v. 82, n. 1, p. 125-132, 2006.

EUCLIDES FILHO, V. P. Desempenho de diferentes grupos genéticos de bovinos de corte em confinamento. Revista Brasileira de Zootecnia, Viçosa, MG, v. 32, n. 5, p. 1114-1122, 2003. 
FEIJÓ, G. L. D.; EUCLIDES FILHO, K.; EUCLIDES, V. P. B.; FIGUEIREDO, G. R. Avaliação das carcaças de novilhos F1 Angus-Nelore em pastagens de Brachiaria decumbens submetidos a diferentes regimes alimentares. Revista Brasileira de Zootecnia, Viçosa, MG, v. 30, n. 3, p. 1015-1020, 2001. Suplemento 1.

FERREIRA, D. F. Sisvar: a computer statistical analysis system. Ciência e Agrotecnologia, Lavras, v. 35, n. 6, p. 1039-1042, 2011.

FERREIRA, I. C.; SILVA, M. A.; BARBOSA, F. A.; CARVALHO, A. D. F.; CORREA, G. S. S.; FRIDRICH, A. B.; SOUZA, J. E. R. Avaliação técnica e econômica de diferentes grupos genéticos de bovinos de corte machos superprecoces e do sistema de produção em confinamento. Arquivos Brasileiros de Medicina Veterinária e Zootecnia, Belo Horizonte, v. 61, n. 1, p. 243-250, 2009.

GOES, R. H. de T.; MANCIO, A. B.; ALVES, D. D.; LANA, R. P.; CECON, P. R.; FREITAS, T. B.; BRABES, K. C. S. Desempenho de novilhos em pastagem submetidos à suplementação protéica e protéico-energética, durante a época seca. Revista Brasileira de Saúde e Produção Animal, Salvador, v. 10, n. 4, p. 907-916, 2009.

KIPPERT, C. J.; RORATO, P. R. N.; LOPES, J. S.; WEBER, T.; BOLIGON, A. A. Efeitos genéticos aditivos diretos e maternos e heterozigóticos sobre os desempenhos pré e pós-desmama em uma população multirracial Aberdeen Angus x Nelore. Revista Brasileira de Zootecnia, Viçosa, MG, v. 37, n. 8, p. 1383-1391, 2008.

LABORDE, F. L.; MANDELL, I. B.; TOSH, J. J.; WILTON, J. W.; BUCHANAN-SMITH, J. G. Breed effects of growth performance, carcass characteristics, fatty acid composition, and palatability attributes in finishing steers. Journal of Animal Sciences, Champaign, v. 79, n. 2, p. 355-365, 2001.

LANCASTER, P. A.; CARSTENS, G. E.; RIBEIRO, F. R. B.; DAVIS, M. E.; LYONS, J. G.; WELSH JUNIOR, T. H. Effects of divergent selection for serum insulinlike growth factor-I concentration on performance, feed efficiency, and ultrasound measures of carcass composition traits in Angus bulls and heifers. Journal of Animal Science, Champaign, v. 86, n. 11, p. 2862-2871, 2008.

LEME, P. R.; BOIN, C.; MARGARIDO, R. C. C.; TEDESCHI, L. O.; HAUSKNECHAT, J. C. O. F. V.; ALLEONI, G. F.; LUCHIARI FILHO, A. Desempenho em confinamento e características de carcaça de bovinos machos de diferentes cruzamentos abatidos em três faixas de peso. Revista Brasileira de Zootecnia, Viçosa, MG, v. 29 , n. 6, p. 2347-2353, 2000. Suplemento 2.
LIMA, W. D.; REZENDE, C. A. P.; BAIÃO, A. A. F.; BAIÃO, E. A. M.; ANDRADE, I. F.; SILVA, A. R. P.; PAIVA, P. C. A.; BAIÃO, L. A. Desempenho de novilhos nelore suplementados em pasto durante época das águas. Ciência e Agrotecnologia, Lavras, v. 28, n. 1, p. 182-190, 2004.

LÔBO, R. N. B.; MARTINS FILHO, N. Avaliação de métodos de padronização dos pesos corporais às idades de 205, 365 e 550 dias. Revista Brasileira de Zootecnia, Viçosa, MG, v. 31, n. 4, p. 1695-1706, 2002.

LOPES, J. S.; RORATO, P. R. N.; WEBER, T.; ARAÚJO, R. O.; DORNELLES, M. A.; COMIN, J. G. Avaliação do desempenho na pós-desmama para uma população bovina multirracial Aberdeen Angus x Nelore utilizandose diferentes modelos genéticos. Arquivos Brasileiros de Medicina Veterinária e Zootecnia, Belo Horizonte, v. 62, n. 6, p. 1439-1447, 2010 b.

Pre-weaning performance evaluation of a

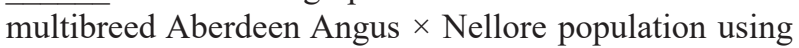
different genetic models. Revista Brasileira de Zootecnia, Viçosa, MG, v. 39, n. 11, p. 2418-2425, 2010a.

LOPES, J. S.; RORATO, P. R. N.; WEBER, T.; BOLIGON, A. A.; COMIN, J. G.; DORNELLES, M. A. Efeito da interação genótipo $\mathrm{x}$ ambiente sobre $\mathrm{o}$ peso ao nascimento, aos 205 e aos 550 dias de idade de bovinos da raça Nelore na região Sul do Brasil. Revista Brasileira de Zootecnia, Viçosa, MG, v. 37, n. 1, p. 5460, 2008.

MUCHENJE, V.; DZAMA, K.; CHIMONYO, M.; RAATS, J. G.; STRYDOM, P. E. Tick susceptibility and its effects on growth performance and carcass characteristics of Nguni, Bonsmara and Angus steers raised on natural pasture. Animal, Cambridge, v. 2, n. 2, p. 298-304, 2008.

PADUA, J. T.; MAGNABOSCO, C. U.; SAINZ, R. D.; MIYAGI, E. S.; PRADO, C. S.; RESTLE, J.; RESENDE, L. S. Genótipo e condição sexual no desempenho e nas características de carcaça de bovinos de corte super jovens. Revista Brasileira de Zootecnia, Viçosa, MG, v. 33, n. 6, p. 2330-2342, 2004.

PEROTTO, D.; MOLETT, J. L.; OLIVEIRA, J. E. P.; LESSKIU, C. Consumo e conversão alimentar de machos bovinos inteiros charolês, caracu e cruzamentos recíprocos em confinamento. Revista Brasileira de Zootecnia, Viçosa, MG, v. 29, n. 1, p. 108-116, 2000.

PIMENTEL, M. A.; MORAES, J. C. F.; JAUME, C. M.; LEMES, J. S.; BRAUNER, C. C. Produção de leite e desempenho pós-parto de vacas Hereford em distintas condições reprodutivas criadas extensivamente. Ciência Rural, Santa Maria, v. 35, n. 1, p. 150-156, 2005. 
REINHARDT, C. D.; BUSBY, W. D.; CORAH, L. R. Relationship of various incoming cattle traits with feedlot performance and carcass traits. Journal of Animal Sciences, Champaign, v. 87, n. 5, p. 3030-3042, 2009.

RESTLE, J.; PACHECO, P. S.; COSTA, E. C.; FREITAS, A. K.; VAZ, F. N.; BRONDANI, I. L.; FERNANDES, J. J. R. Apreciação econômica da terminação em confinamento de novilhos Red Angus super jovens abatidos com diferentes pesos. Revista Brasileira de Zootecnia, Viçosa, MG, v. 36, n. 4, p. 978-986, 2007.

RESTLE, J.; PASCOAL, L. L.; FATURI, C.; ALVES FILHO, D. C.; BRONDANI, I. L.; PACHECO, P. S.; PEIXOTO, L. A. O. Efeito do grupo genético e da heterose nas características quantitativas da carcaça de vacas de descarte terminadas em confinamento. Revista Brasileira de Zootecnia, Viçosa, MG, v. 31, n. 1, p. 350362, 2002. Suplemento.

RIBEIRO, A. R. B.; ALENCAR, M. M.; FREITAS, A. R.; REGITANO, L. C. A.; OLIVEIRA, M. C. S.; IBELLI, A. M. G. Heat tolerance of Nelore, Senepol x Nelore and Angus x Nelore heifers in the southeast region of Brazil. South African Journal of Animal Science, Pretoria, v. 39, n. 1, p. b263-265, 2009. Suplemento 1.

RIBEIRO, E. L. A.; HERNANDEZ, J. A.; ZANELLA, E. L.; MIZUBUTI, I. Y.; SILVA, L. D. F.; REEVES, J. J. Desempenho e características de carcaça de bovinos de diferentes grupos genéticos. Revista Brasileira de Zootecnia, Viçosa, MG, v. 37, n. 9, p. 1669-1673, 2008.

SÁ, J. F.; PEDREIRA, M. S.; SILVA, F. F. da; FIGUEIREDO, M. P. de; REBOUÇAS, G. M. N.; SOUZA, D. R. de. Cinética da fermentação in vitro do capim-Marandu em diferentes idades de corte. Acta Scientiarum Animal Sciences, Maringá, v. 33, n. 3, p. 225-231, 2011.
SILVA, A. H. G. da; RESTLE, J.; MISSIO, R. L.; BILEGO, U. O.; FERNANDES, J. J. de R.; REZENDE, P. L. de P.; SILVA, R. M. da; PEREIRA, M. L. R.; LINO, F. A. Milheto em substituição ao milho na dieta de novilhos confinados. Semina: Ciências Agrárias, Londrina, v. 35, n. 4, p. 2077-2094, 2014.

SILVA, S. L.; LEME, P. R.; PUTRINO, S. M.; MARTELLO, L. S.; LIMA, C. G.; LANNA, D. P. D. Estimativa da cobertura de gordura ao abate, por ultrasom, em tourinhos brangus e nelore. Revista Brasileira de Zootecnia, Viçosa, MG, v. 33, n. 2, p. 511-517, 2004.

SILVA GOULART, R. S.; ALENCAR, M. M.; POTT, E. B.; CRUZ, G. M.; TULLIO, R. R.; ALLEONI, G. F.; LANNA, D. P. D. Composição corporal e exigências líquidas de proteína e energia de bovinos de quatro grupos genéticos terminados em confinamento. Revista Brasileira de Zootecnia, Viçosa, MG, v. 37, n. 5, p. 926935, 2008.

VIEIRA, A.; LOBATO, J. F. P.; ALMEIDA TORRES JUNIOR, R. A.; CEZAR, I. M.; CORREA, E. S. Recria de machos nelore em pastagens cultivadas com suplementação na seca nos cerrados do Brasil central. Revista Brasileira de Zootecnia, Viçosa, MG, v. 34, n. 4, p. 1349-1356, 2005.

YANG, J.; FERREIRA, R.; DUPONTE, M. W.; FUKUMOTO, G. K.; ZHAO, B. Growth performances of $\mathrm{F} 1$ angus plus calves grazing on pasture in Hawaii's tropical climate. Edinburgh, v. 41, n. 4, p. 593-598, 2009. 